\title{
Hyperbaric Oxygen in Epidural Fibrosis: Is There a Potential for Treatment?
}

\author{
Epidural Fibrozis İcin Hiperbarik Oksijen: Tedaviye Katkısı Var mı?
}

\author{
Alp Ozgun BORCEK ${ }^{1}$, Pelin BORCEK ${ }^{2}$, Soner CIVI ${ }^{1}$, Hakan EMMEZ ${ }^{1}$, Ahmet SEN ${ }^{3}$, Sükrü AYKOL ${ }^{1}$ \\ ${ }^{1}$ Gazi University, Faculty of Medicine, Department of Neurosurgery, Ankara, Turkey \\ ${ }^{2}$ Gazi University, Faculty of Medicine, Department of Pathology, Ankara, Turkey \\ ${ }^{3}$ Gulhane Military Medical Academy, Aerospace Medicine, Eskisehir, Turkey
}

Corresponding Author: Alp Ozgun BORCEK / E-mail: alpob@yahoo.com

\begin{abstract}
AIM: To investigate the effects of hyperbaric oxygen treatment on epidural fibrosis formation in an experimental laminectomy model.

MATERIAL and METHODS: Twenty-four Wistar rats underwent L5-L6 total laminectomy and divided into three groups. Animals in the control group received no further treatment while animals in short and long term groups received 2,5 ATM ABS of hyperbaric oxygen for 3 and 7 days, respectively. The amount of epidural fibrosis was analyzed histologically at the end of 42 days of follow up.

RESULTS: The ratio of severe fibrosis was $57 \%$ in the control, $29 \%$ in the short HBOT, and $14 \%$ in the long HBOT groups. Although there was a clear trend towards having less fibrosis in the HBOT groups, the difference did not reach to the level of statistical significance ( $p=0.242$ ), probably due to small number of animals used in this preliminary study.

CONCLUSION: Our findings suggest that hyperbaric oxygen treatment may have favorable effects on epidural fibrosis. Further studies with larger cohorts are required to prove our results
\end{abstract}

KEYWORDS: Epidural fibrosis, Failed back syndrome, Hyperbaric oxygen, Laminectomy, Peridural fibrosis

öz

AMAÇ: Bu çalışmada, deneysel laminektomi modeli kullanılarak ratlarda oluşturulan epidural fibrosis ve buna bağlı olarak gözlenen ağrı cevabı üzerine hiperbarik oksijen tedavisinin etkilerinin incelenmesi amaçlanmıştır.

YÖNTEM ve GEREÇLER: Yirmi dört wistar cinsi rata L5 L6 seviyelerinden total laminektomi yapılıp ratlar rastgele bir şekilde 3 gruba ayrılmıştır. Kontrol grubundaki hayvanlar her hangi bir ek tedavi almazken kısa ve uzun süreli tedavi gruplarındaki hayvanlara sırası ile 3 ve 7 gün boyunca 2.5 ATM ABS hiperbarik oksijen tedavisi uygulanmıştır. Kırkiki günlük takip süresi sonunda laminektomi sahasındaki epidural fibrosis miktarı histolojik olarak değerlendirmiştir.

BULGULAR: Grade 3 fibrozis kontrol grubunda \%57 oranında gözlenirken kısa HBOT grubunda \%29; uzun HBOT grubunda ise \%14 oranında gözlenmiştir. Her ne kadar HBOT alan gruplarda daha az fibrozis gözlenmiş olsa da gruplar arasındaki farklar istatistiksel olarak anlamlı bulunmamıştır ( $p=0.242)$. Bunun nedeninin, bu öncü çalışmada kullanılan hayvan sayısının azlığı olarak düşünülmüştür.

SONUÇ: Çalışma bulguları hiperbarik oksijen tedavisinin epidural fibrozis üzerine olumlu etkileri olabileceğini göstermektedir. Daha çok deneğin katıldığı farklı dizaynda çalışmalara ihtiyaç duyulmaktadır.

ANAHTAR SÖZCÜKLER: Epidural fibrozis, Başarısız bel cerrahisi sendromu, Hiperbarik oksijen, Laminektomi, Peridural fibrozis

\section{INTRODUCTION}

Failed back surgery syndrome is continued low back pain with or without radicular pain after lumber surgery. One important factor leading to this syndrome is the fibrotic scar tissue formed at the surgery site causing mass effect and nerve damage $(5,11,14)$. Epidural fibrosis can be defined as excessive fibrotic scar tissue formation at the epidural space after surgery and it is estimated that as high as $25 \%$ of the patients suffering from failed back surgery syndrome have epidural fibrosis (7).

Undersea and Hyperbaric Medical Society defines hyperbaric oxygen treatment (HBOT) as a treatment modality where the patient breaths $100 \%$ oxygen intermittently while the pressure of the treatment chamber is increased to greater than one atmosphere absolute (ATM ABS). Besides its various indications, it has proven effects on wound healing $(1,3,6,12,15,17-19)$ and inflammation $(2,4,9,13,16)$.

There are various studies in the literature aiming to solve epidural scar formation reporting variable success rates. Using an experimental animal model, this study aims to investigate the effects of hyperbaric oxygen treatment (HBOT) on epidural fibrosis. Wound healing process and formation of epidural fibrosis have similar mechanisms that may give valuable information for solving this problem. This is the first study utilizing hyperbaric oxygen for epidural scar formation. 


\section{MATERIAL and METHODS}

\section{Animal Preparation}

Twenty-four Wistar rats weighing between 250-300 g were used in this study. Before the study, animals were housed in the laboratory for 10 days for adaptation. Animals were kept under constant laboratory conditions of $18^{\circ} \mathrm{C}$ to $21^{\circ} \mathrm{C}$ room temperature, a 12-hour light-dark cycle, and were allowed free access to standard rat feed and tap water. All experimental procedures were approved by Gazi University Board of Ethics and performed in accordance with the local guidelines in research to minimize animal discomfort.

\section{Surgical Procedure}

Surgical procedures were performed under sterile conditions using basic surgical tools, electrical drill and surgical microscope. General anesthesia was induced by intraperitoneal injection of $35 \mathrm{mg} / \mathrm{kg}$ ketamine (Ketalar, Pfizer, Istanbul) and $15 \mathrm{mg} / \mathrm{kg}$ xylazine (Rompun, Bayer, Istanbul). After marking rats with ear tags, their lower back was shaved and prepared using $\% 10$ polyvinylpyrrolidone/ iodine. Spinous process of the $L 5$ vertebra was marked with a needle and the location of the vertebra was confirmed with $X$-ray in order to standardize the approach for exposing the $L 5$ roots. After determining the $L 5$ spinous process, a midline incision form L4 to L6 was made. The lumbosacral fascia was incised and the paraspinal musculature was dissected away from the bony elements of the vertebrae. With the help of the surgical microscope and the electrical drill, L5 and L6 laminectomy was performed and the $\mathrm{L} 5$ roots were exposed. Normal saline Irrigation and gentle compression with surgical pads were used for hemostasis. Bone wax, surgicell, cotton and electrocautery were avoided due to their possible effects on postoperative fibrosis. After adequate hemostasis, incisions were closed in layers.

After the surgical procedure, animals were kept in individual cages during the recovery phase. After recovery, they were examined for neurological deficits. Throughout the experiment all of the animals were kept in same conditions and they were allowed to mobilize freely in their cages of same dimensions.

\section{Description of Groups}

After the surgical procedure, animals were randomly assigned into three groups. Animals were tagged regarding their groups. The groups were as follows:
Group 1: (Control Group) Animals in this group received no further treatment after the surgery.

Group 2: (Short HBO Group) Animals in this group received hyperbaric oxygen therapy after the surgery according to the predefined treatment protocol entailing HBO exposure every 24 hours for 3 days.

Group 3: (Long HBO Group) Animals in this group received hyperbaric oxygen therapy after the surgery according to the predefined treatment protocol entailing $\mathrm{HBO}$ exposure every 24 hours for 7 days.

\section{Hyperbaric Oxygen Treatment}

Treatment sessions for each animal started after full recovery. An animal chamber was used for treatment. After flushing the chamber with $100 \%$ oxygen for 10 minutes, animals were placed into the chamber. The starting time was recorded for each animal. The pressure of the chamber was gradually increased to 2,5 ATM ABS in 10 minutes and maintained at this level for the following 90 minutes. At the end of the 90 minutes, the pressure was gradually decreased to atmospheric pressure in 10 minutes. This protocol was administered to the animals in Groups 2 and 3, for 3 and 7 days respectively.

\section{Histopathological Evaluation}

At the end of the 6 week (day 42), animals were killed with intraperitoneal $100 \mathrm{mg} / \mathrm{kg}$ sodium thiopental (Pentothal Sodyum, Abbott, İstanbul). The lumbar spines were removed en block using a circular saw and then placed in $10 \%$ buffered formalin. After fixation, specimens were placed in $10 \%$ formic acid solution for decalcification and paraffin blocks were made after 3 weeks. Axial sections of $6 \mu \mathrm{m}$ form the laminectomy site were cut with a microtome and were stained with hematoxylin-eosin and Masson's trichrome. Slides were evaluated by a pathologist in a blinded fashion.

The extent of the epidural fibrosis at the laminectomy scar was recorded according to the criteria defined by He et al (10). These criteria are presented in Table I.

\section{Statistical Analysis}

Differences between groups regarding epidural fibrosis were analyzed using Kruskal-Wallis test. $P$ value $<0.05$ was considered as statistically significant.

\section{RESULTS}

None of the animals died during the surgical procedures and at the end of the follow-up period. There were no

Table I: Scale for Evaluating the Extent of the Epidural Fibrosis

\begin{tabular}{|l|l|}
\hline Grade & Description \\
\hline Grade 0 & No scar formation over the dura mater \\
\hline Grade 1 & Thin fibrotic bands between the dura mater and the scar tissue \\
\hline Grade 2 & Fibrosis filling less than $2 / 3$ of the laminectomy site \\
\hline Grade 3 & Fibrosis filling more than $2 / 3$ of the laminectomy site and/or fibrosis extending to nerve roots. \\
\hline
\end{tabular}


complications attributable to the surgical intervention (i.e. neurological deficit, wound infection).

Figure 1 displays distribution of epidural fibrosis between groups. There was no Grade 0 fibrosis in any of the animals. The ratio of Grade 3 fibrosis in the short and long HBOT groups was ( $n=2 ; 29 \%$ and $n=1 ; 14 \%$, respectively) lower than in the control group (57\%). On the other hand, the ratio of Grade 1 fibrosis was $17 \%(n=1)$ in the control group and it was observed in $33 \%(n=2)$ of the short HBOT group and $50 \%$ $(n=3)$ of the long HBOT group. Figure 2, 3, 4 demonstrates different grades of epidural fibrosis at the laminectomy site. The difference was not statistically significant $(p=0.242)$.

\section{DISCUSSION}

This study aims to investigate the effects of HBOT on epidural fibrosis. The three-day long HBOT was administered during the homeostasis and inflammation phases of wound healing while the seven-day long HBOT was administered during these two phases as well as the proliferation phase.

Grade 3 fibrosis was observed in 57\% of the animals in the control group and this ratio was higher than the HBOT groups. Grade 3 fibrosis was observed in $29 \%$ of the animals in the short HBOT group and in 14\% of the animals in the long HBOT group. In this study, animals receiving hyperbaric oxygen (HBO) showed lowest epidural fibrosis scores. We think that the main reason for not reaching statistically significant conclusions is the limited number of animals in groups. Larger cohorts could reveal significant results.

The hypothesis of this study was that HBOT will reduce the extent of the epidural fibrosis and the results obtained from the study supports our hypothesis. HBO has direct effects in wound healing processes. In their study on rabbit medial collateral ligament fibroblasts, Chan et al have demonstrated that hyperbaric oxygen reduces Type III collagen while

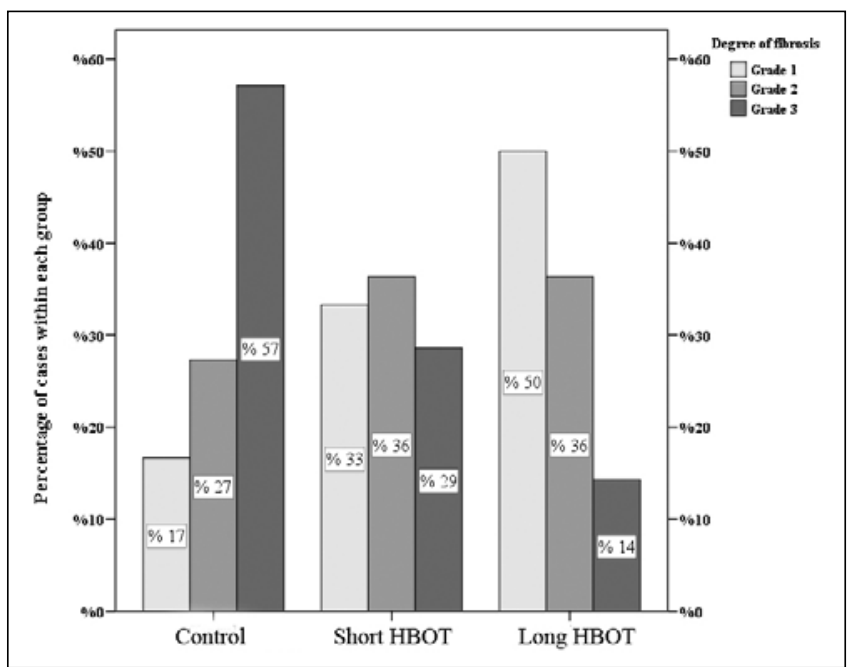

Figure 1: Bar graph demonstrating the distribution of epidural fibrosis between groups. Each bar represent the percentage of cases in each group regarding their fibrosis grade.

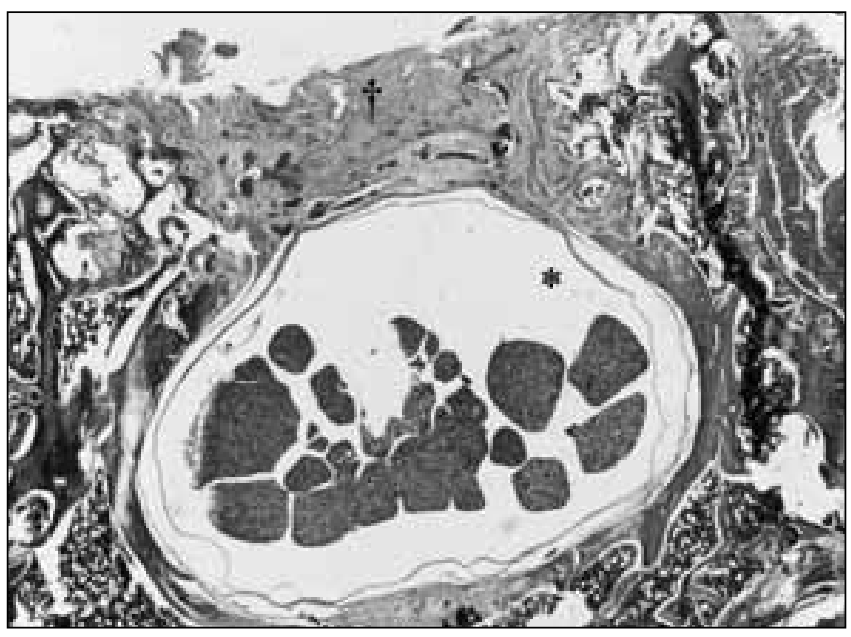

Figure 2: Photomicrograph of Grade 1 fibrosis at the laminectomy site (Masson's Trichrome, x 20. * spinal cord; † laminectomy area).

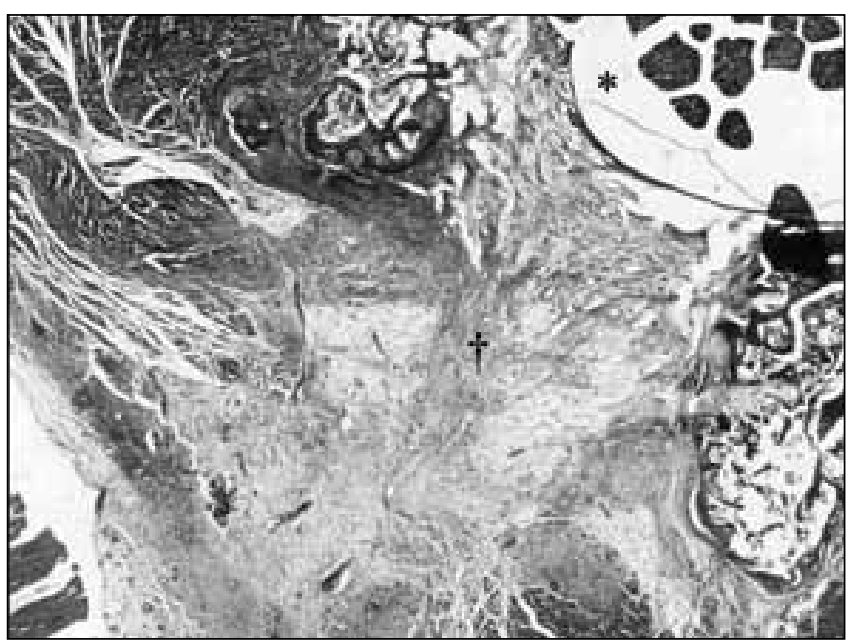

Figure 3: Photomicrograph of Grade 2 fibrosis at the laminectomy site (Masson's Trichrome, x 20. * spinal cord; † laminectomy area).

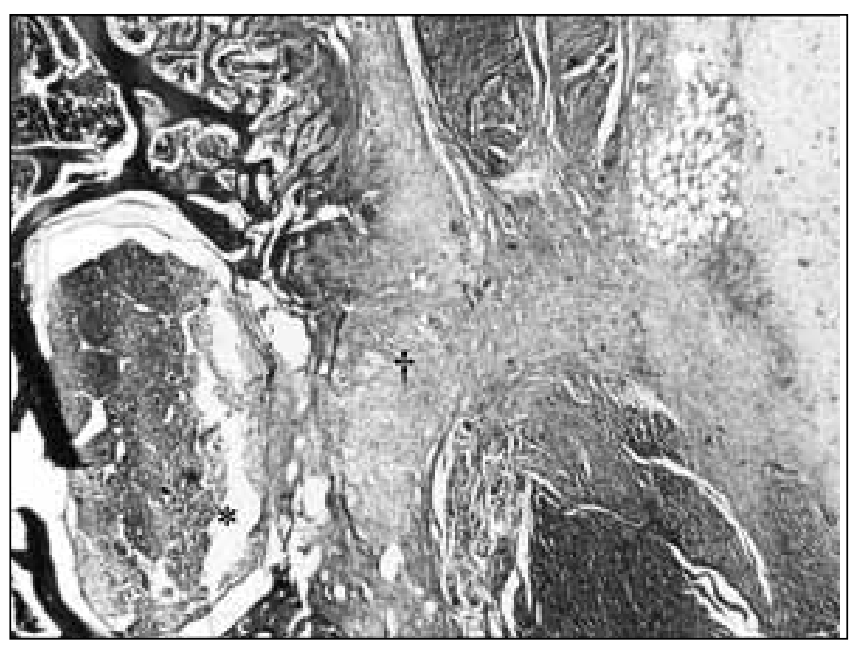

Figure 4: Photomicrograph of Grade 3 fibrosis at the laminectomy site (Masson's Trichrome, $\times 20 .{ }^{*}$ spinal cord; + laminectomy area). 
increasing Type I collagen and this leads to stronger collagen fiber formation (4). Increase in Type I collagen in healing environment results in mechanically more stable wound. In another study, Hadjipanayi et al have found that pressure increases fibroblast proliferation in wound (8) which lead to a stronger wound architecture. The HBOT treatment provides a high oxygenated environment under high pressures and help to constitute a mechanically more stable wound healing in early phases of wound healing. We believe that, this early mechanical stabilization of the wound with the help of HBOT prevents redundant scar formation and results in less fibrosis.

Epidural fibrosis and its consequences has been the target of many drugs, adhesive barriers, surgical interventions, conservative treatment modalities with no satisfying benefit. Considering the proven effects of hyperbaric oxygen treatment in various disorders, we hypothesize that it may also be useful in prevention of epidural fibrosis.

\section{CONCLUSION}

Hyperbaric oxygen treatment has long been used as a successful tool for important problems of modern medicine and is a promising method for many other diseases. HBOT treatment may have positive effects on unwanted scar formation in operated tissues. Additional studies with larger cohorts and different experimental settings on HBOT may add another weapon to the armamentarium for failed back syndrome.

\section{REFERENCES}

1. 7th European consensus conference on hyperbaric medicine. Lille: European Committee for Hyperbaric Medicine, 2004

2. Benson RM, Minter LM, Osborne BA, Granowitz EV: Hyperbaric oxygen inhibits stimulus-induced proinflammatory cytokine synthesis by human blood-derived monocyte-macrophages. Clin Exp Immunol 134:57-62, 2003

3. Bonomo SR, Davidson JD, Tyrone JW, Lin X, Mustoe TA: Enhancement of wound healing by hyperbaric oxygen and transforming growth factor beta3 in a new chronic wound model in aged rabbits. Arch Surg 135:1148-1153, 2000

4. Chan YS, Chen AC, Yuan LJ, Lin SS, Yang CY, Lee MS, Ueng SW: Effects of hyperbaric oxygen and platelet derived growth factor on medial collateral ligament fibroblasts. Undersea Hyperb Med 34:181-190, 2007

5. Devereaux MW: Low back pain. Prim Care 31:33-51, 2004
6. Fife CE: Hyperbaric Oxygen Therapy. In: Falabella AF, Kirsner RS (eds), Wound Healing. New York: Taylor\&Francis, 2005: 573586

7. Gasinski P, Radek M, Jozwiak J, Lyczak P: Peridural fibrosis in lumbar disc surgery--pathogenesis, clinical problems and prophylactic attempts. Neurol Neurochir Pol 34:983-993, 2000

8. Hadjipanayi E, Mudera V, Brown RA: Close dependence of fibroblast proliferation on collagen scaffold matrix stiffness. J Tissue Eng Regen Med 2008

9. Hansbrough JF, Piacentine JG, Eiseman B:Immunosuppression by hyperbaric oxygen. Surgery 87:662-667, 1980

10. He $Y$, Revel M, Loty B: A quantitative model of postlaminectomy scar formation. Effects of a nonsteroidal antiinflammatory drug. Spine 20:557-563, 1995

11. Krishnaney AA, Park J, Benzel EC: Surgical management of neck and low back pain. Neurol Clin 25:507-522, 2007

12. Roeckl-Wiedmann I, Bennett M, Kranke P: Systematic review of hyperbaric oxygen in the management of chronic wounds. Br J Surg 92:24-32, 2005

13. Slotman GJ: Hyperbaric oxygen in systemic inflammation. HBO is not just a movie channel anymore. Crit Care Med 26:1932-1933, 1998

14. Sypert GW, Arpin-Sypert EJ: Evaluation and management of the Failed Back Syndrome. Winn HR, Youmans JR (eds), Youmans Neurological Surgery, Vol: 4, 5th ed. Philadelphia: W.B. Saunders, 2004: 4327-4347

15. Thackham JA, McElwain DL, Long RJ: The use of hyperbaric oxygen therapy to treat chronic wounds: A review. Wound Repair Regen 16:321-330, 2008

16. van den Blink B, van der Kleij AJ, Versteeg $\mathrm{HH}$, Peppelenbosch MP: Immunomodulatory effect of oxygen and pressure. Comparative Biochemistry and Physiology - Part A: Molecular \& Integrative Physiology 132:193-197, 2002

17. Wang C, Schwaitzberg S, Berliner E, Zarin DA, Lau J: Hyperbaric oxygen for treating wounds: A systematic review of the literature. Arch Surg 138:272-279; discussion 280, 2003

18. Yildiz S, Uluutku H, Gunay A, Yildirim I, Yildirim S, Gurbuz AK: The effect of hyperbaric oxygen therapy on the adverse effects of octreotide on wound healing. Eur J Gastroenterol Hepatol 16:475-478, 2004

19. Zamboni WA, Browder LK, Martinez J: Hyperbaric oxygen and wound healing. Clin Plast Surg 30:67-75, 2003 